\title{
$\mathrm{Nb}$ 가 첨가된 신형 지르코늄 피복관의 열적 크리프 거동
}

\author{
김준환 ${ }^{\dagger} \cdot$ 방제건 · 정용환 \\ 한국원자력연구소 지르코늅 신합금 개발팀
}

\section{Thermal Creep Behavior of Advanced Zirconium Claddings Contained Niobium}

\author{
Jun Hwan Kim ${ }^{\dagger}$, Je Geon Bang and Yong Hwan Jeong \\ Zirconium Fuel Cladding Development Team, Korea Atomic Energy Research Institute, Daejeon, 305-353 Korea
}

(2004년 5월 17일 받음, 2004년 6월 22일 최종수정본 받음)

\begin{abstract}
Thermal creep properties of the zirconium tube which was developed for high burnup application were evaluated. The creep test of cladding tubes after various final heat treatment was carried out by the internal pressurization method in the temperature range from $350^{\circ} \mathrm{C}$ to $400^{\circ} \mathrm{C}$ and from 100 to $150 \mathrm{MPa}$ in the hoop stress. Creep tests were lasted up to 900days, which showed the steady-state secondary creep rate. The creep resistance of zirconium claddings was higher than that of Zircaloy-4. Factors that affect creep resistance, such as final annealing temperature, applied stress and alloying element were discussed. Tin as an alloying element was more effective than niobium due to solute hardening effect of tin. In case of advanced claddings, the optimization of final heat treatment temperature as well as alloying element causes a great influence on the improvement of creep resistance.
\end{abstract}

Keywords Creep, Zirconium, Cladding, Niobium, Annealing

\section{1. 서 론}

원자력발전소에서 쓰이는 핵연료 피복관은 핵연료를 가 두며 핵분열 생성물이 냉각수 내로 유입되는 것을 막아 주는 중요한 노심재료중의 하나이다. 핵연로 피복관의 외 부 표면은 약 $15.4 \mathrm{MPa}$ 압력하의 $320^{\circ} \mathrm{C}$ 냉각수에 노출 되어 있다. 핵연료 피복관은 고온, 고압의 부식환경과 중 성자 조사로 인한 재료의 취화 및 성장현상으로 인한 기 계적 성질의 저하를 겪을 수 있기 때문에 재료의 선정 에 특하 주의를 요한다. 지르코늄 합금은 고온에서의 기 계적 강도, 크리프 저항성, 내부식성 및 열전도성이 우 수하고, 중성자 흡수성이 적기 때문에 지르코늄 합금이 원자로의 핵연료 피복관으로 널리 사용되고 있다. 현재 원자력 발전소는 경제적 운전을 위해 고연소도, 장주기 운전, 고온 냉각재 및 높은 냉각수 $\mathrm{pH}$ 운전 등을 시도 하고 있는 추세이며 기존에 사용되고 있는 지르칼로이4 피복관은 이와 같은 극심한 부식환경에서 사용하기가 어려운 현실이다. 이에 원자로의 경제성 제고와 안전성 향상을 위하여 파손 신뢰도 및 열적 여유도 등이 크게 항상된 새로운 핵연료봉 개발이 요구되고 있으며 이를 만 족시키기 위해서는 무엇보다도 내식성 및 크리프 저항성

${ }^{\dagger}$ E-Mail : junhkim@kaeri.re.kr
이 향상된 신형 피복관을 개발하는 일이다. 현재 미국, 프랑스, 일본, 러시아 등 외국 원전 선진국에서 신형 피 복관 개발을 활발히 추진하고 있고 한국원자력연구소도 현재 신형 피복관 시제품을 제조하였으며 이에 대한 노 외시혐이 진행 중에 있다. 개발된 신형 피복관의 최근 추 세는 내부식성 향상에 염두를 두어 부식에 악영향을 미 치는 $\mathrm{Sn}$ 함량을 줄이고 부식 저항성을 높이는 $\mathrm{Nb}$ 함량 을 높이고 있는 실정이다 ${ }^{1.2)}$. 지르칼로이-4 등과 같이 $\mathrm{Nb}$ 가 첨가되지 않은 피복관에 대한 크리프 거동 연구는 많 이 이루어졌으나 ${ }^{3-5)}$, 피복관의 크리프에 미치는 $\mathrm{Nb}$ 의 영 향에 대하여는 그 연구가 미미한 실정이다. 본 연구의 목 적은 한국원자력연구소가 개발한 $\mathrm{Nb}$ 가 첨가된 신형 피 복관의 열적 크리프 거동을 비교, 검토하는데 있으며 이 에 피복관의 크리프에 미치는 인자를 인가응력, 시험온 도, 최종열처리, 합금원소의 영향으로 나누어서 분석하였다.

\section{2. 실험 방법}

\section{1 실험 재료}

실험에 사용된 지르코늄 피복관의 화학 조성은 Table. 1 과 같으며 피복관 $\mathrm{C}$ 와 $\mathrm{D}$ 는 비교적 낮은 $\mathrm{Nb}$ 함량과 높 은 $\mathrm{Sn}$ 을 가진 반면, 피복관 $\mathrm{E}$ 는 낮은 $\mathrm{Sn}$ 과 높은 $\mathrm{Nb}$ 함 량을 가지고 있다. 피복관 $\mathrm{H}$ 의 경우, $\mathrm{Sn}$ 함량 없이 
Table 1. Chemical composition of zirconium claddings

\begin{tabular}{ccccc}
\hline \hline $\mathrm{ID}$ & $\mathrm{Nb}$ & $\mathrm{Sn}$ & Others & $\mathrm{Zr}$ \\
\hline $\mathrm{C}$ & 0.4 & 0.8 & 0.6 & Bal. \\
$\mathrm{D}$ & 0.2 & 1.1 & 0.6 & Bal. \\
$\mathrm{E}$ & 1.5 & 0.4 & 0.3 & Bal. \\
$\mathrm{H}$ & 1.2 & - & 0.1 & Bal. \\
Zry-4 & - & 1.3 & 0.3 & Bal. \\
\hline
\end{tabular}

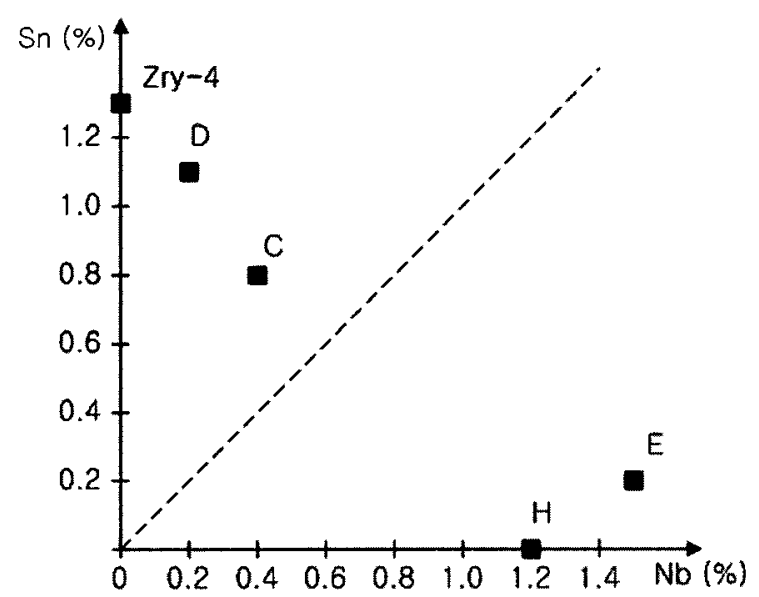

Fig. 1. Schematic illustration on the chemical composition of test claddings

$1.2 \%$ 의 $\mathrm{Nb}$ 를 합금원소로 가지고 있다. Fig. 1 에 시험에 사용된 피복관의 조성을 모식화하여 나타내었다. 제조한 피복관을 다양한 열처리 공정에에 따라 제조하여 크리프 시험에 이용하였다. 일반적으로 지르코늅 합금의 크리프 거동은 가공공정중 중간열처리 변화보다는 최종열처리 변 화에 매우 민감한 경향을 보인다. 본 연구에서는 피복관 $\mathrm{C}$ 와 $\mathrm{D}$ 는 최종열처리를 각각 $440^{\circ} \mathrm{C}, 470^{\circ} \mathrm{C}, 520^{\circ} \mathrm{C}$, $580^{\circ} \mathrm{C}$ 씩 3 시간 열처리를 수행하여 시험하였으며 피복관 $\mathrm{E}$ 와 $\mathrm{H}$ 는 최종열처리를 $470^{\circ} \mathrm{C}, 520^{\circ} \mathrm{C}$ 씩 3 시간 열처리한 시편을 사용하여 장기 크리프 시험을 수행하여 최종열처 리가 크리프 성질에 미치는 영향을 연구하고자 하였다. 피복관의 실험결과를 비교하기 위해 기준 피복관으로 지 르칼로이-4 피복관을 이용하여 비교하였다. 기준 피복관 은 별도의 열처리를 수행하지 않고 입수상태(As-received) 그대로 크리프 시험에 이용하였다.

\section{2 크리프 시험}

지르코늄 피복관의 열적 크리프 거동을 평가하기 위하 여 내압 튜브 크리프 장치를 이용하여 시험하였다. 시험 온도에서 $100,120,135,150 \mathrm{MPa}$ 의 원주응력을 갖게 아 르곤 기체를 장입한 피복관을 용접, 밀봉한 후 $350^{\circ} \mathrm{C}$ 와 $400^{\circ} \mathrm{C}$ 의 분위기로(furnace)에 놓고 30 일 간격으로 지름의 변화를 측정하였다. 크리프 변형량은 마이크로 메타를 사

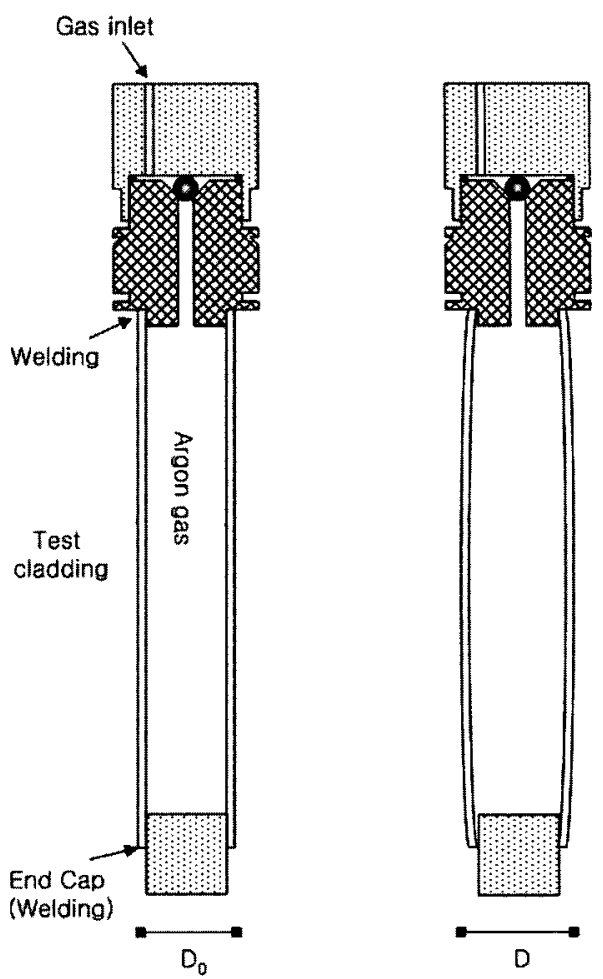

Fig. 2. Schematic illustration of the internal pressurized tube specimen for the creep test

용하여 시편 중간부위 3 군데를 측정하여 평균값을 취하 였으며 크리프 변형은 시간에 따른 지름의 변화량을 초 기 지름으로 나누어서 구하였다. Fig. 2에 튜브형 크리 프 시편의 개략도를 나타내었다. 열적 크리프의 경우 크 리프 변형률은 시험 온도와 인가응력간의 함수로 나타널 수 있으며 그 관계식은 다음과 같이 나타낼 수 있다.

$$
\dot{\varepsilon}=A \sigma^{\mathrm{n}} \exp \left(-\frac{\mathrm{Q}}{\mathrm{RT}}\right)
$$

여기서 $\mathrm{A}$ 는 재료특성 및 미세구조에 관련있는 상수이 며, $\mathrm{n}$ 은 속도지수, $\mathrm{Q}$ 는 온도에 따른 활성화 에너지이다. 본 연구에서는 (1)의 관계식을 이용하여 $\mathrm{K}$-피복관의 응 력에 따른 응력지수와 활성화 에너지를 구하여 크리프 기 구를 예상하는데 사용하였다.

\section{3. 결과 및 고찰}

\section{1 장기 크리프시험 결과}

Fig. 3은 지르코늄 합금의 부분 재결정 온도인 $520^{\circ} \mathrm{C}$ 에서 열처리한 지르코늄 피복관 및 지르칼로이-4 피복관 의 크리프 변형량을 나타낸 결과이다. 피복관 $\mathrm{C}$ 는 700 일, $\mathrm{D}$ 는 900 일, 피복관 $\mathrm{E}$ 와 피복관 $\mathrm{H}$ 까지는 각각 600 일 크리프 시험을 수행한 결과이며 피복관에 따라 크리 프 시간이 다른 이유는 시제품 피복관을 제조한 순서대 


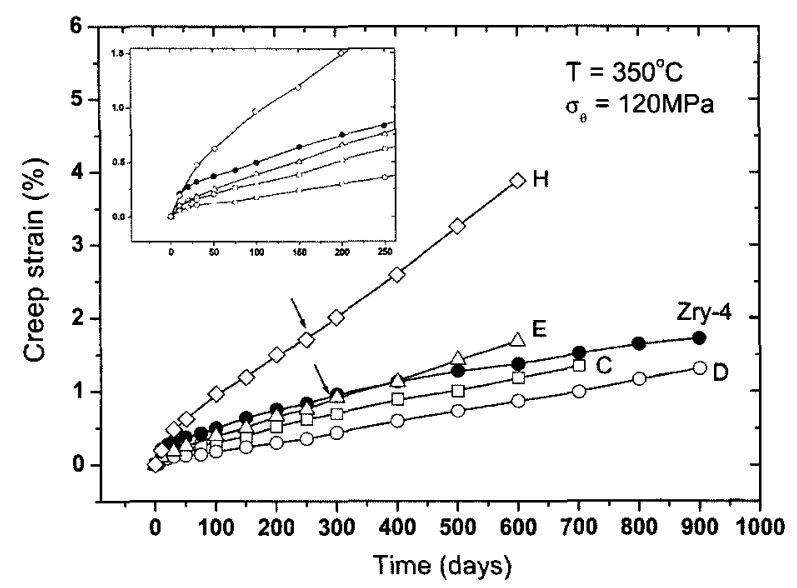

Fig. 3. Thermal creep properties of zirconium claddings heat treated in partially recrystalized conditions

로 크리프 시험을 순차적으로 시험한 결과 소요시간이 시 제품별로 다르게 산출되었기 때문이다. 현재 각 피복관 모두 정상상태의 안정한 2차 크리프 변형 거동을 보이 고 있다. 재결정 온도에서 열처리 한 경우 응력이완조건 에 비하여 공통적으로 크리프 속도가 현저히 감소한 것 으로 관찰되고 있으며 $\mathrm{D}, \mathrm{C}$, 지르칼로이 $-4, \mathrm{E}, \mathrm{H}$ 의 순 서로 크리프 변형률의 순서를 보이고 있다. $\mathrm{Nb}$ 의 함량 이 높을수록 크리프 저항성이 다소 떨어지는 거동을 보 이고 있으며, 재결정온도 열처리의 경우, 900 일 실험을 기준으로 비교하면 피복관 $\mathrm{D}$ 가 다른 피복관에 비하여 우 수한 저항성을 보이고 있으며 reference 피복관인 지르 칼로이-4의 크리프 속도의 80\%에 불과한 우수한 크리프 거동을 보이고 있다. 적은 $\mathrm{Sn}$ 함량을 지닌 피복관 $\mathrm{E}$ 와 $\mathrm{H}$ 의 경우 300 일을 전후하여 2 차 크리프 속도가 정상속 도에서 다소 벗어나서 증가하기 시작하는 거동을 보인 반 면 (Fig. 3의 화살표) 많은 $\mathrm{Sn}$ 함량을 지닌 피복관 $\mathrm{C}$ 와 $\mathrm{D}$ 는 시간에 따라 일정한 정상상태의 2 차 크리프 속도를 보이고 있다. 정상상태의 크리프 변형이 가동전위와 용 질원자의 상호작용이 평형을 이룬 상태로 가정한다면 변 형이 진행될수록 크리프 강도를 결정짓는 기지 내에 고 용된 용질 원자가 생성된 전위망에 고착되어 초기에 균 일하게 분포된 용질원자는 점차 불균일한 분포를 이루게 된다 ${ }^{18,199}$. 피복관 $\mathrm{C}, \mathrm{D}$ 에 비해 상대적으로 적은 고용 용 질원소를 지닌 피복관 $\mathrm{E}$ 와 $\mathrm{H}$ 에서 곹 불균일한 용질원 소 분포를 나타내게 되어 용질원자가 국부적으로 고갈된 지역에서 변형이 우선적으로 일어나게 되어 이것이 크리 프 속도를 정상상태보다 높게 만든 요인으로 작용한 것 으로 보인다.

Fig. 4는 응력이완 열처리를 수행한 지르코늄 피복관 의 시간에 따른 크리프 변형률의 변화를 도시한 그래프 이다. 각 합금의 변형률이 다양하기 때문에 변형률의 변 화를 합금별로 명확히 보기 위하여 초기의 변형률 값으

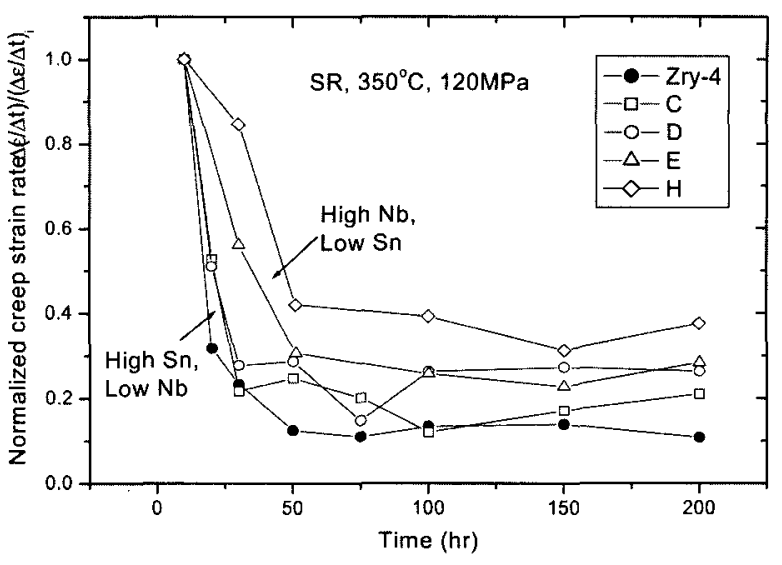

Fig. 4. Time dependency on the creep strain rate of zirconium cladding normalized by initial strain rate after stress-relieved heat treatment

로 나누어 정규화한 변형률을 시간에 따라 도시하였다. 각 합금 공통적으로 초기에는 크리프 속도가 높은 1차 크리프 거동을 보이다가 점차 크리프 속도가 시간에 따 라 일정해지는 2 차 크리프 영역으로 진입함을 관찰할 수 있었다. 2 차 크리프 진입시간은 합금에 따른 차이를 볼 수 없었으나 장입 후 대략 75일을 전후로 관찰되었다. 초기에 가동전위가 움직이기 시작하면서 피복관의 변형 률은 높아지다가 점차 용질원자의 확산이 평형을 이루면 서 이것이 가동전위의 움직임을 지체시켜 크리프 속도를 낮추게 된다. 지르칼로이-4와 피복관 $\mathrm{C}$ 와 $\mathrm{D}$ 같이 초기 $\mathrm{Sn}$ 함량이 높은 피복관은 시간에 따른 크리프 변형률의 감 소가 빠른 반면, 초기 $\mathrm{Sn}$ 함량이 낮은 피복관 $\mathrm{E}$ 와 $\mathrm{H}$ 는 시간에 따른 크리프 변형률의 변화폭이 작았다. 이는 가 동전위의 움직임을 지체시키는 요인이 기지내의 용질원 자의 양에 좌우되는 것으로 사료된다.

\section{2 최종열처리의 영향}

최종열처리 영향을 명확히 보기 위하여 각 피복관에 대 하여 최종열처리를 $440^{\circ} \mathrm{C}$ 부터 $580^{\circ} \mathrm{C}$ 까지 변화시켜 $350^{\circ} \mathrm{C}$ 시험온도에서 크리프 변형률을 측정하였다. Fig. 5 는 이러한 최종열처리 온도의 영향에 따른 피복관의 크 리프 속도를 나타낸 결과이며 각 피복관은 공통적으로 최 종열처리 온도가 높아질수록 크리프 속도가 감소하는 거 동을 보이고 있다. 크리프 변형기구가 전위활주 및 상승 에 의존하는 경우, 최종열처리 온도가 높아질수록 석출 물의 크기가 증가하여 가동전위가 석출물을 뛰어넘기에 필요한 열에너지를 받기까지 시간이 소요되어 이것이 크 리프 저항성을 높이는 요인으로 작용하며 ${ }^{7)}$, 변형기구가 공공의 입계 및 입내확산에 의하여 결정립이 연신하는 확 산 크리프의 경우, 열처리 온도가 높아질수록 결정립이 성장하여 공공확산에 푈요한 경로가 늘어나서 공공이동 에 필요한 시간이 늘어나게 되어 이것이 피복관의 크리 


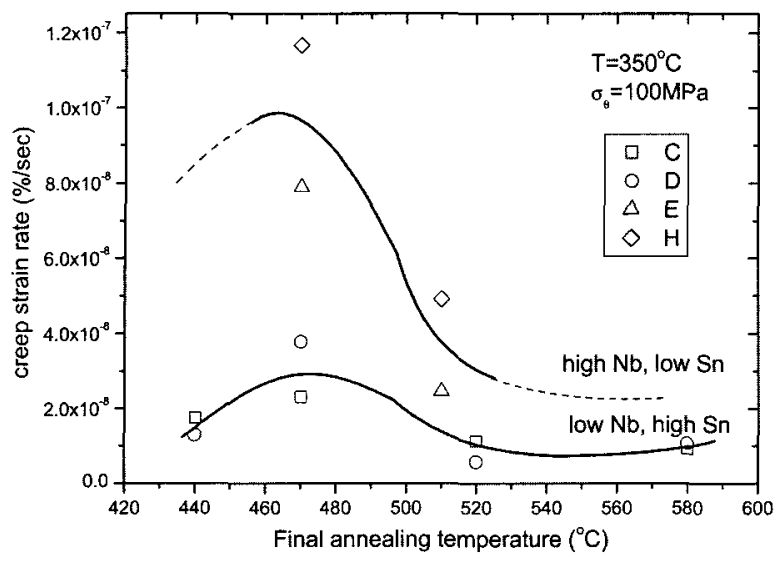

Fig. 5. Effect of final heat treatment on the creep strain rate of zirconium cladding

프 저항성을 높이는 요인으로 작용하는 것으로 보인다 ${ }^{8)}$ 또한 최종열처리 온도가 올라갈수록 합금내에 존재하는 초기 전위망이 소멸되어 크리프 변형에 필요한 전위망이 형성되기 까지 시간이 소요되기 때문에 크리프 속도가 떨 어지는 것으로 보인닫. 피복관 $\mathrm{E}, \mathrm{H}$ 의 크리프 속도가 피복관 $\mathrm{C}, \mathrm{D}$ 의 속도보다 빠른 반면, 열처리 온도가 증 가할수록 그 감소폭이 매우 큰 양상을 보였다. $\mathrm{Nb}$ 가 첨 가된 지르코늄 합금의 경우, 첨가된 $\mathrm{Nb}$ 의 함량이 높을 수록 동일한 열처리 온도에서도 재결정이 용이하지 않은 경향을 나타내고 있는데 ${ }^{9)}$ 이는 $\mathrm{Nb}$ 가 $\beta$ 상 안정화 원소 여서 $\alpha$ 상 형성을 억제하는 구실을 함과 동시에 $\mathrm{Nb}$ 의 낮 은 확산속도로 인하여 동일한 열처리 온도에서도 재결정 이 용이하지 못한 거동을 보여주기 때문이다 ${ }^{20)}$. 열처리 온도가 높아질수록 높은 $\mathrm{Nb}$ 함량을 가진 피복관의 크리 프 속도의 감소폭이 컸다. 이는 앞에서 서술한 바와 같 이 열처리 온도가 높아질수록 피복관의 $\alpha$ 상 재결정이 급 격하게 일어남과 동시에 석출된 $\mathrm{Nb}$ 가 기지내로 고용되 어 가동전위가 고착되는 효과에 의하여 피복관의 크리프 속도가 빠르게 감소하는 것으로 보인다.

\section{3 응력지수 및 활성화 에너지}

Fig. 6는 인가응력에 따른 피복관 $\mathrm{C}$ 의 크리프 변형을 나타내는 그림이다. 인가 원주응력이 증가할수록 크리프 속도는 증가하는 거동을 보이고 있으며 $100 \mathrm{MPa}$ 보다 $150 \mathrm{MPa}$ 에서 열처리 온도의 증가에 따른 크리프 속도 감 소영향이 두드러지게 나타났다. Table 2는 C, D, E, H

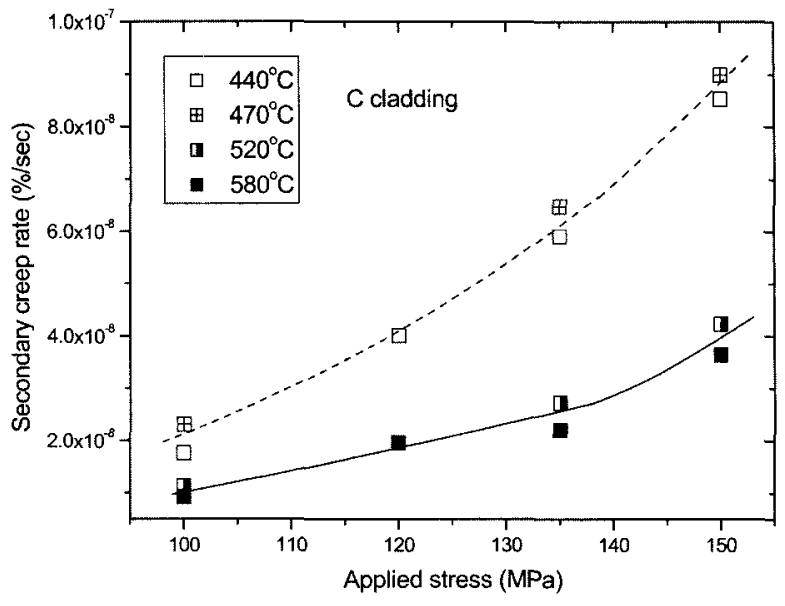

Fig. 6. Effect of applied stress and final heat treatment on the creep strain rate of zirconium cladding

피복관과 지르칼로이-4에 대한 열처리 조건에 다른 크리 프 인자를 나타낸 표이다. $\mathrm{Nb}$ 가 적게 첨가된 $\mathrm{C}, \mathrm{D}$ 피 복관은 응력이완 열처리에서 응력지수가 3.37 과 5.35 로 서 다소 높게 나온 반면, $\mathrm{Nb}$ 를 많이 함유한 $\mathrm{E}, \mathrm{H}$ 피복 관은 응력지수가 2.94 와 2.63 으로서 비교적 낮은 값이 나 왔다. 그러나 재결정 열처리시 낮은 $\mathrm{Nb}$ 를 함유한 $\mathrm{C}$ 와 $\mathrm{D}$ 피복관의 응력지수는 감소한 반면, $\mathrm{Nb}$ 의 함량이 많은 $\mathrm{E}$ 와 $\mathrm{H}$ 피복관은 응력지수가 다소 증가하는 거동을 보 인다. 지르코늠 합금의 응력지수는 일반적으로 응력지수 가 1 에서 3 인 경우 크리프 변형기구가 공공의 확산에 기 인하는 확산 크리프머 응력지수가 3에서 7인 경우 가동 전위의 활주가 재료 내 용질원자의 확산에 의하여 조절 되는 전위 크리프 기구가 주를 이루며, 응력지수가 7 이 상이면 크리프 변형기구가 가동전위가 용질원자의 고착 에서 자유로와지며 전위활주 후 장애물에서 전위의 상승 에 의하여 결정되는 전위상승 (dislocation-climb) 크리프 를 보이고 있는 것으로 알려져 있닥. 본 연구에 사용 된 피복관의 크리프 변형기구는 공통적으로 기지내의 용 질원자가 가동전위 활주와 상호작용을 일으켜 이것이 전 체 크리프 변형을 제어하는 전위 활주 크리프 거동을 보 이고 있는 것으로 보인다. $\mathrm{Nb}$ 를 함유한 피복관 $\mathrm{E}, \mathrm{H}$ 의 경우, $\mathrm{Nb}$ 의 낮은 확산속도에 기인한 미세한 결정립의 형 성으로 인하여 기지내의 공공 확산에 의한 확산 크리프 의 영향이 다소 작용하여 이것이 피복관의 응력지수를 낮 추는 요인을 작용한 것으로 보인다. 활성화 에너지는 $\mathrm{K}-$

Table 2. Stress exponent and activation energy of zirconium claddings

\begin{tabular}{lcccccccccc}
\hline \multicolumn{1}{c}{ ID } & \multicolumn{2}{c}{$\mathrm{C}$} & \multicolumn{3}{c}{$\mathrm{D}$} & & $\mathrm{E}$ & & $\mathrm{H}$ & Zry-4 \\
\hline Heat Treatment & SR & PR & SR & PR & SR & PR & SR & PR & SR \\
n $\left(350^{\circ} \mathrm{C}\right)$ & 3.37 & 3.17 & 5.35 & 4.75 & 2.94 & 3.05 & 2.63 & 3.93 & 3.47 \\
Q (kcal/mole) & 62.8 & 55.7 & 52.2 & 64.2 & 50.9 & 50.8 & 48.2 & 51.4 & 49.9 \\
\hline
\end{tabular}


피복관의 경우 50 에서 $60 \mathrm{kcal} / \mathrm{mole}$ 의 값으로서 열처리에 따른 활성화 에너지의 변화는 감지하기 어려웠으며 이 값 은 일반적으로 알려진 $\mathrm{Zr}-1.3 \mathrm{Sn}$ 합금의 자체확산 활성화 에너지인 $62 \mathrm{kcal} / \mathrm{mole}$ 과 비슷한 값을 보이고 있다 ${ }^{9}$. 활 성화 에너지는 일반적으로 시험 온도에 따라 민감하며 낮 은 온도인 $200^{\circ} \mathrm{C}$ 영역에서는 작은 값을 보이다가 원자 로 가동온도인 $350^{\circ} \mathrm{C}$ 에서 상승하는 거동을 보이며 이는 지르코늄 합금의 동적시효현상에 기인한다고 알려져 있 다 ${ }^{11,12)}$. 지르칼로이-4 및 $\mathrm{C}, \mathrm{D}, \mathrm{E}, \mathrm{H}$ 피복관에 대한 $350^{\circ} \mathrm{C}$ 인장시험 ${ }^{13)}$ 에서 동적변형시효가 관찰되었고 본 연 구에서는 2 차 크리프의 활성화 에너지가 지르코늠 기지 내에서 산소원자의 활성화 에너지인 $30 \mathrm{kcal} / \mathrm{mole}$ 보다 높 은 값을 보이고 있다 ${ }^{18)}$.

\section{4 합금원소의 영향}

Fig. 3에서 시간에 따른 피복관의 크리프 거동은 $\mathrm{Nb}$ 의 함량이 증가할수록 피복관의 크리프 속도가 증가하는 거동을 보였으며 $\mathrm{Sn}$ 이 첨가된 경우 크리프 거동이 개선 되고 있음을 관찰되고 있다. $\mathrm{Sn}$ 의 첨가는 고용강화를 유 발하여 피복관 크리프 성질을 개선시키는 반면, $\mathrm{Nb}$ 는 일 정 함량 이상 첨가시 강화기구가 고용강화에서 석출강화 로 전환되고 이러한 석출강화는 느린 크리프 보다 빠른 크리프 속도에서 영향을 보인다고 알려져 있다 ${ }^{14)} . \mathrm{Zr}$ $0.2 \mathrm{Nb}$ 와 $\mathrm{Zr}-1.0 \mathrm{Nb}$ 에 대한 크리프 시험결과 ${ }^{9}$ 에 의하면, $1.0 \mathrm{wt} \% \mathrm{Nb}$ 을 첨가한 합금이 $0.2 \mathrm{wt} \%$ 를 첨가한 합금보다 전위밀도와 석출물이 많이 분포하고 있으며 석출물의 크 기도 다양함이 보고되고 있다. 그러나 석출물에 의한 가 동전위 고착 현상은 석출물의 밀도와 분포에 크게 좌우 하기 때문에 일정 밀도이하의 석출물과 균일하지 않은 석 출물 분포는 오히려 가동전위의 움직임을 조장하여 크리 프 속도를 빠르게 할 수 있다는 연구보고도 있다 ${ }^{15)} . \mathrm{Sn}$ 은 기지 내에 고용되어 이것이 재료 격자내의 내부응력 을 증가시켜 가동전위의 움직임을 둔화시킬 뿐 아니라 기 지원자의 확산을 방해하는 역할을 동시에 담당한다. 또 한 $\mathrm{Sn}$ 은 $\alpha$ 지르코늄 내의 적층결함 에너지(Stacking Fault Energy)를 감소시켜 가동전위의 교차슬립 및 상승 을 억제하는 구실을 담당하고 있다 ${ }^{16)} . \mathrm{E}, \mathrm{H}$ 피복관의 크 리프 거동이 낮은 이유가 $\mathrm{Nb}$ 의 첨가에 따른 초기 전위 밀도의 증가와 재결정 현상의 둔화가 발생하며 이울러 $\mathrm{Sn}$ 함량의 감소로 인한 고용강화 현상의 감소도 지르코늄 합 금의 크리프 저항성 감소에 큰 영향을 행사하는 것으로 사료된다. 판재형 시편의 크리프 저항성에 대한 합금원 소 효과는 $\mathrm{Sn}$ 함량과 $0.5 \mathrm{wt} \%$ 이하의 $\mathrm{Nb}$ 함량에 의해 좌우된다고 알려져 있으며 ${ }^{9)}$ 이러한 경향은 피복관 tube 에서도 동일한 효과를 보일 것으로 생각된다. 이와 같이 크리프 저항성에 영향을 미치는 것이 석출강화보다 고용 강화임에 착안하여 합금 강화지수 $\mathrm{F}$ 를 다음과 같이 설
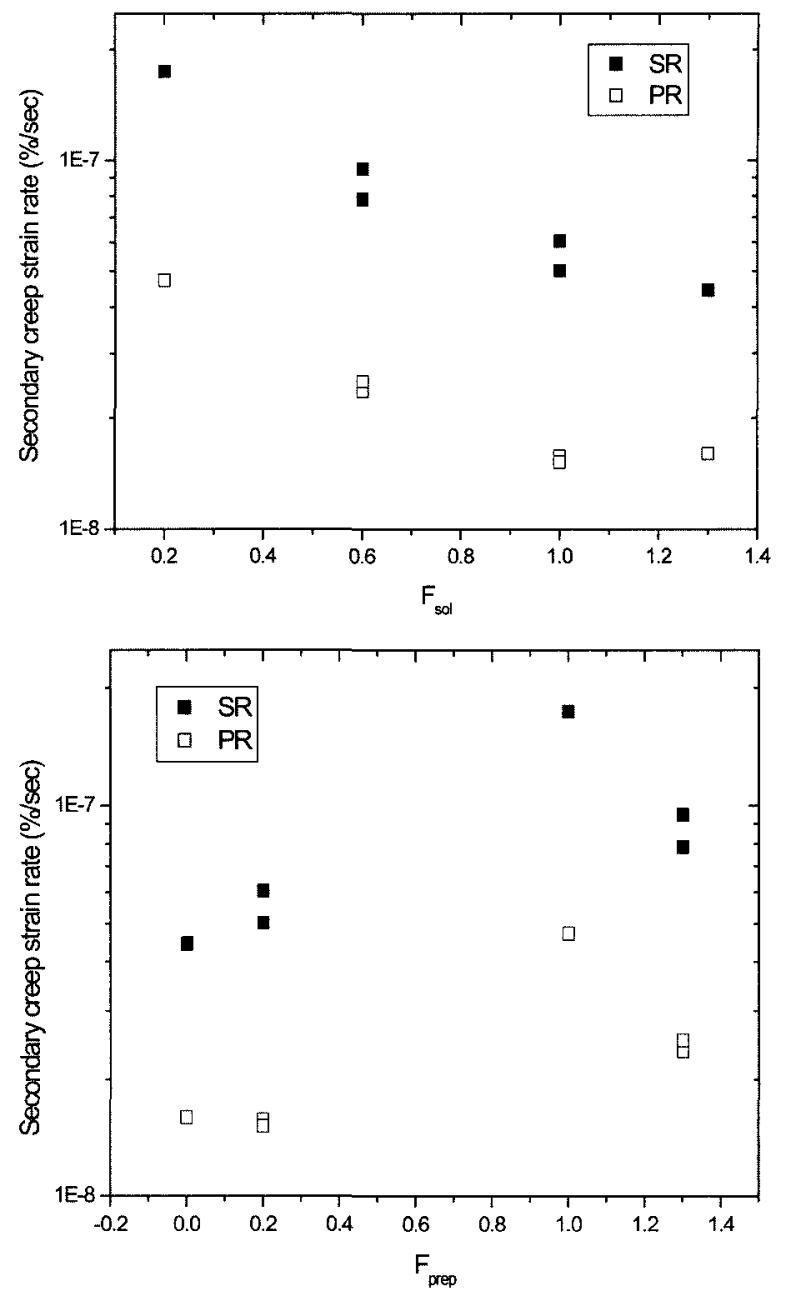

Fig. 7. Effect of hardening index on the creep resistance of zirconium cladding with various alloying content. Creep preformed at $350^{\circ} \mathrm{C}, 120 \mathrm{MPa}$.

정하였다.

$$
\begin{aligned}
& F_{\text {sol }}=C_{S n}+C_{N b} \\
& F_{\text {pre }}=C_{N b}^{*}-C_{N b}
\end{aligned}
$$

여기서 $\mathrm{F}_{\text {sol }}$ 과 $\mathrm{F}_{\mathrm{pre}}$ 는 각각 고용강화와 석출강화에 관 련된 합금 강화지수를 의미하고 $\mathrm{C}_{\mathrm{Sn}}$ 과 $\mathrm{C}_{\mathrm{Nb}}$ 는 해당온도 에서 $\mathrm{Sn}$ 과 $\mathrm{Nb}$ 의 고용도를 나타내며 $\mathrm{C}^{*} \mathrm{Nb}$ 는 첨가 $\mathrm{Nb}$ 의 양을 나타낸다. 크리프 온도인 $350^{\circ} \mathrm{C}$ 에서 $\mathrm{Sn}$ 의 고 용도가 2 내지 $3 \%$ 인 반면 $\mathrm{Nb}$ 의 고용도는 $0.2 \%$ 에 불과 하다 ${ }^{17)}$. Fig. 7은 도출한 합금강화지수에 다른 크리프 변 형속도를 나타낸 그림이다. 고용강화지수가 증가할수록 각 합금의 크리프 저항성이 증가하는 반면 석출강화지수가 증가할수록 크리프 저항성이 나빠지는 것이 뚜렷이 관찰 되고 있다. 


\section{4. 결 론}

한국원자력연구소에서 개발한 신형 피복관에 대하여 최 장 900 일 동안 열적 크리프 시험을 수행한 결과 다음 과 같은 결론을 얻을 수 있었다.

1) 시제품 피복관에 대한 장기 크리프 시험 결과 피 복관 $\mathrm{C}$ 와 $\mathrm{D}$ 의 경우, 지르칼로이 -4 보다 우수한 크리프 성능을 보이고 있다.

2) 본 연구결과, $\mathrm{Nb}$ 및 $\mathrm{Sn}$ 의 첨가와 관계없이 최종열 처리온도가 증가할수록 크리프 속도는 감소하는 거동을 보였다.

3) 지르코늄 피복관의 크리프와 관련된 주요 변형기구 는 원자력발전소 가동온도에서는 가동전위의 활주가 용 질원자의 확산에 영향받는 크리프가 주로 작용하였으며 합금원소에 따라 변형기구가 다소 변화를 보였다.

4) 고용도 이하의 $\mathrm{Nb}$ 첨가와 $\mathrm{Sn}$ 첨가가 기지내의 용 질원자 농도를 증가시켜 크리프 저항성을 높이는 역할로 작용하였으며 개발된 신형 지르코늄 피복관의 크리프 거 동은 합금원소의 영향과 아울러 최종 열처리 온도에 크 게 영향받는 것으로 생각된다.

\section{감사의 글}

본 연구는 과학기술부의 원자력연구개발사업인 “지르 코늠신합금 핵연료피복관 개발 과제”의 일환으로 수행 되었음.

\section{참 고 문 헌}

1. G. P. Sabol, G. R. Kilp, M. G. Balfour and E. Roberts, ASTM STP 1023, 227 (1989).

2. J. P. Mardon, D. Charquet and J. Senevat, ASTM STP
1354, 505 (2000).

3. D. B. Knorr and M. R. Notis, J. Nucl. Mater., 56, 18 (1975).

4. M. Limback and T. Andersson, ASTM STP 1295, 448 (1996).

5. J. M. Frenkel and M. Weisz, ASTM STP 551, 140 (1974).

6. C. Nam, B. K. Choi, Y. H. Jeong and Y. H. Jung, Proc. the Korean Nuclear Society Fall Meeting (2002).

7. D. G. Frankline, G. E. Lucas and A. L. Bement, ASTM STP 815 (1983).

8. I. M. Bernstein, Trans. Am. Inst. Met. and Pet. Eng. 239, 1518 (1967).

9. K. H. Kim C. Nam, M. H. Lee, Y. H. Jeong and Y. H, Jung, Proc. the Korean Nuclear Society Fall Meeting (1999).

10. Y. G. Yoon, Y. H. Jeong and B. K. Choi, J. Kor. Inst. Met. \& Mater., 39, 8, 864 (2001).

11. J. J. Holmes, J. Nucl. Mater. 13, 2 (1964).

12. B. Ranaswami and G. B. Craig, Trans. Am. Inst. of Met. and Pet. Eng. 239, 1226 (1967).

13. M. H. Lee, J. H. Kim, S. Y. Park, J. G. Bang, B. K. Choi, Y. H. Jeong and Y. H. Jung, Proc. of the Korean Nuclear Society Spring Meeting (2004).

14. C. Nam, K. H. Kim, M. H. Lee and Y. H. Jeong, J. Kor. Nucl. Soc. 32, 372 (2000).

15. R. Brenner, J. L. Bëchade, O. Castelnau and B. Bacroix, J. Nucl. Mater., 305, 175 (2002).

16. W. A. McInteer, D. L. Baty and K. O. Stein, ASTM STP 1023, 621 (1989).

17. Metals Handbook, vol. 8, 8th ed, p.285, American Society for Metals, Ohio (1973).

18. N. Christodoulou, P. A. Turner, C. N. Tomë, C. K. Chow and R. J. Klassen, Metal. and Mater. Trans. 33A, 1103 (2002).

19. K. U. Snowden, J. Nucl. Mater. 36, 347 (1970).

20. T. Forgeron, J. C. Brachet, F. Barcelo, A. Castaing, J. Hivroz, J. P. Mardon and C. Bernaudat, ASTM STP 1354, $256(2000)$. 